\title{
EDITORIAL
}

\section{Gestational Diabetes Mellitus: From controversies of yesterday to consensus of today}

\author{
Adeleke NA.
}

From the days of O' Sullivan and Mahan, the diagnosis in women who developed hyperglycemia for the first time during pregnancy has been plagued with controversy. It took sometime before the definition proposed by the American Diabetes Association, "any degree of glucose intolerance with onset or first recognition during pregnancy' was accepted (1). The definition subsists whether abnormal blood glucose was present before pregnancy but not detected and whether or not it resolves after delivery. Diagnostic criteria for Gestational Diabetes Mellitus (GDM) have been a subject of debate - do we use the same set of plasma glucose values as in non-pregnant women? Realizing that pregnancy is a unique state and harm may have occurred to the developing foetus at a lower blood glucose level than that for diabetes in the non-pregnant state, workers have now agreed on the criteria which set a lower blood glucose value for the diagnosis of GDM(1).

Before now, screening methods and the gestational age to screen varied worldwide. However, with the better understanding of the pathophysiology of GDM, 24-32 weeks of pregnancy was recommended for diagnosis. Similarly, most authorities now accept routine Oral Glucose Tolerance Test, as the preferred method of screening and diagnosis, as the use of clinical risk factors will lead to missing about one-third of women who have GDM (2). Any of the following plasma glucose values of $\geq 92 \mathrm{mg} / \mathrm{dl}(5.1 \mathrm{mmol} / \mathrm{l}), 1 \mathrm{hr}$ $\geq 180 \mathrm{mg} / \mathrm{dl}(10.0 \mathrm{mmol} / \mathrm{l})$ and $2 \mathrm{hr} \geq 153 \mathrm{mg} / \mathrm{dl}(8.5 \mathrm{mmol} / \mathrm{l})$ post-glucose load is used for diagnosis (2). The use of 3 hours and initial 50gm glucose challenge is limited to the United States.

Treatment of GDM in the past comprise of diet, exercise and insulin only (3). However, evidence now exist supporting satisfactory outcome with the use of oral medications like sulphonylurea such as glibenclamide (glyburide) and metformin (3).

Complications of untreated GDM includes pre-eclampsia/eclampsia, cesarean section in the mother and macrosomia, birth trauma, neonatal hypoglycemia, hyperbilirubinemia all combined to produce high perinatal death in the babies, while both are at high risk of developing type $2 \mathrm{DM}$, cardiovascular diseases, and metabolic syndrome later in life (2).

The convergences of opinions were achieved through international conferences, WHO, WDF and IDF commissioned works. The consensus recommendations are flexible for the rich and poor nations to adapt (4), one such adaptation is the use of fasting blood glucose alone in the diagnosis of GDM in resource poor setting. The universal implementation of these recommendations for practice will ensure satisfactory outcome from GDM pregnancies and help to reduce type $2 \mathrm{DM}$.

\section{References:}

1. Metzger BE, Lowe LP, Dyer AR et al. Hyperglycemia and adverse pregnancy outcomes. N Engl J Med 2008; 358: 1991-2002

2. International Association of Diabetes in Pregnancy Groups Consensus Panel. International association of diabetes and pregnancy study groups recommendations on the diagnosis and classi? cation of hyperglycemia in pregnancy. Diabetes Care 2010; 33: 676-682.

3. Christopher J. Nolan (2011) Treatment of GDM. Controversies in gestational diabetes. Best Practice \& Research Clinical Obstetrics and Gynaecology 25 37-49.

4. The International Federation of Gynecology and Obstetrics, FIGO.(2015) Initiative on Gestational Diabetes Mellitus: A Pragmatic Guide for Diagnosis, Management, and care. International Journal of Gynecology \& Obstetrics IJGO. Volume 131, Supplement 3.

Department of Obstetrics and Gynaecology, Osun State University, Osogbo.

Adeleke NA. MBBS: FWACS

Email:najemdeen.adeleke@uniosun.edu.ng

Research Journal of Health Sciences subscribed to terms and conditions of Open Access publication. Articles are distributed under the terms of Creative Commons Licence (CC BY-NC-ND 4.0). (http://creativecommons.org/licences/by-nc-nd/4.0). 


\title{
ÉDITORIAL
}

\section{Diabète gestationnel Mellitus: des controverses d'hier au consensus d'aujourd'hui}

\begin{abstract}
Adeleke NA.
Depuis les jours d'O 'Sullivan et Mahan, le diagnostic chez les femmes qui ont développé l'hyperglycémie pour la première fois pendant la grossesse a été en proie à la controverse. Il a fallu un certain temps avant la définition proposée par l'American Diabetes Association, «tout degré d'intolérance au glucose avec apparition ou première reconnaissance pendant la grossesse» a été acceptée (1). La définition s'applique à savoir si le glucose sanguin anormal était présent avant la grossesse mais n'a pas été détecté et si oui ou non il se résout après l'accouchement. Les critères diagnostiques pour le diabète sucré gestationnel (GDM) ont fait l'objet de débats - utilisons-nous le même ensemble de valeurs de glucose plasmatiques que chez les femmes non enceintes? Réalisant que la grossesse est un état unique et le mal peut avoir eu lieu au fœetus en développement à un niveau inférieur de glucose sanguin que celui pour le diabète dans l'état non enceinte, les travailleurs ont maintenant accepté les critères qui fixent une glycémie inférieure pour le diagnostic De $\operatorname{GDM}(1)$.
\end{abstract}

Auparavant, les méthodes de dépistage et l'âge gestationnel à l'écran variaient dans le monde entier. Cependant, avec une meilleure compréhension de la pathophysiologie de GDM, 24-32 semaines de grossesse a été recommandée pour le diagnostic. De même, la plupart des autorités acceptent maintenant le test de tolérance à la glycémie, comme méthode préférée de dépistage et de diagnostic, car l'utilisation de facteurs de risque cliniques entraînera la disparition d'un tiers environ des femmes qui ont un MGD (2). L'une des valeurs suivantes de glucose plasmatique $=92 \mathrm{mg} / \mathrm{dl}(5.1 \mathrm{mmol} / 1), 1 \mathrm{~h}=180 \mathrm{mg} / \mathrm{dl}(10.0 \mathrm{mmol} / \mathrm{l})$ et $2 \mathrm{hr}{ }^{3} 153 \mathrm{mg} / \mathrm{dl}(8.5 \mathrm{mmol} / \mathrm{l})$ de charge post-glucose est utilisée pour Diagnostic (2). L'utilisation de 3 heures et le défi initial de $50 \mathrm{~g}$ de glucose est limitée aux États-Unis.

Le traitement de la GDM dans le passé ne comprend que l'alimentation, l'exercice et l'insuline (3). Cependant, il existe maintenant des preuves permettant d'obtenir des résultats satisfaisants avec l'utilisation de médicaments oraux comme les sulfonylurées comme le glibenclamide (glyburide) et la metformine (3).

Les complications de la GDM non traitée incluent la pré-éclampsie / éclampsie, la césarienne chez la mère et la macrosomie, le traumatisme à la naissance, l'hypoglycémie néonatale, l'hyperbilirubinémie se combinent pour produire une mortalité périnatale élevée chez les bébés, alors que les deux présentent un risque élevé de diabète de type 2 Les maladies et le syndrome métabolique plus tard dans la vie (2).

Les convergences d'opinions ont été obtenues par le biais de conférences internationales, de l'OMS, de la WDF et des travaux commandés par la FID. Les recommandations consensuelles sont souples pour les pays riches et les pays pauvres à s'adapter (4), une telle adaptation est l'utilisation de la glycémie à jeun seule dans le diagnostic de GDM dans un environnement pauvre en ressources. La mise en œuvre universelle de ces recommandations pour la pratique assurera des résultats satisfaisants des grossesses GDM et aidera à réduire le $\mathrm{DM}$ de type 2 .

Department of Obstetrics and Gynaecology, Osun State University, Osogbo.

Adeleke NA. MBBS: FWACS

Email:najemdeen.adeleke@uniosun.edu.ng

References:

1. Metzger BE, Lowe LP, Dyer AR et al. Hyperglycemia and adverse pregnancy outcomes. NEngl J Med 2008; 358: 1991-2002

2. International Association of Diabetes in Pregnancy Groups Consensus Panel. International association of diabetes and pregnancy study groups recommendations on the diagnosis and classi? cation of hyperglycemia in pregnancy. Diabetes Care 2010; 33: 676-682.

3. Christopher J. Nolan (2011) Treatment of GDM. Controversies in gestational diabetes. Best Practice \& Research Clinical Obstetrics and Gynaecology $2537-49$.

4. The International Federation of Gynecology and Obstetrics, FIGO.(2015) Initiative on Gestational Diabetes Mellitus: A Pragmatic Guide for Diagnosis, Management, and care. International Journal of Gynecology \& Obstetrics IJGO. Volume 131, Supplement 3. 